\title{
PENGGUNAAN BUBUK ABATE UNTUK MENURUNKAN DERAJAT INFESTASI DAN MERUSAK ORGAN PARASIT Argulus YANG MENGINFESTASI IKAN MAS (Cyprinus carpio)
}

\section{Utilization of abate powder to demote the infestation and organ impairing degree of Argulus in gold fish (Cyprinus carpio)}

\author{
Mohammad Faizal Ulkhaq ${ }^{1 *}$, Darmawan Setia Budi ${ }^{1}$, Hapsari Kenconojati ${ }^{1}$, dan Muhammad Hanif \\ Azhar ${ }^{1}$ \\ ${ }^{1}$ Program Studi Akuakultur, Fakultas Perikanan dan Kelautan Universitas Airlangga Kampus Banyuwangi \\ *m-faizalulkhaq@fpk.unair.ac.id
}

\begin{abstract}
Abstrak
Kematian ikan akibat serangan parasit Argulus dikarenakan ikan mengalami emasiasi sehingga dapat menurunkan sistem kekebalan tubuh ikan. Selain itu munculnya luka pada kulit ikan akan dimanfaatkan sebagai port of entry bagi agen infeksi sekunder seperti jamur, bakteri dan virus. Pengendalian penyakit argulosis dengan dosis bahan kimia yang tidak tepat dapat mencemari lingkungan sehingga perlu dicari alternatif bahan kimia yang aman terhadap lingkungan seperti abate. Tujuan dari penelitian ini adalah untuk mengetahui efektivitas perendaman abate dalam menurunkan derajat infestasi dan merusak organ parasit Argulus yang menginfestasi ikan mas (Cyprinus carpio). Perlakuan yang diberikan terdiri dari lima perlakuan dengan empat kali ulangan yaitu pemberian abate dengan konsentrasi 0 ppm (kontrol), 25 ppm, 50 ppm, 75 ppm, dan 100 ppm yang direndam selama 30 menit. Parameter yang diamati pada penelitian ini adalah derajat infestasi Argulus yang menempel pada ikan mas, kerusakan organ Argulus dan nilai kualitas air pada awal dan akhir perendaman sebagai parameter pendukung. Data derajat infestasi Argulus pada ikan mas dianalisis secara statistik menggunakan ANOVA 5\% yang dilanjutkan dengan uji DMRT 5\%. Sedangkan kerusakan organ Argulus dianalisis secara deskriptif dan disajikan dalam bentuk gambar dan tabel serta dihubungkan dengan parameter pendukung. Hasil penelitian menujukkan bahwa perendaman abate tidak efektif dalam menurunkan derajat infestasi Argulus, akan tetapi dapat menimbulkan kerusakan organ Argulus pada perlakuan 100 ppm. Kerusakan organ Argulus yang ditimbulkan yaitu rontoknya kaki ke-3 dan 4, abdomen yang menyatu serta produksi telur prematur. Perlu dilakukan penelitian lanjutan dengan meningkatkan dosis abate (lebih dari $100 \mathrm{ppm}$ ) serta waktu inkubasi yang lebih lama (lebih dari 30 menit). Selain itu perlu diamati perubahan fisiologis ikan selama dilakukan perendaman dalam abate.
\end{abstract}

Kata kunci: Derajat infestasi, Kerusakan organ, Abate, Argulus

\begin{abstract}
Mortality by Argulus caused fish emaciation, decreasing the immune system and appearance of the lesion in the skin that will be used as port of entry for secondary infection such as bacteria, fungi, and virus. Controlling of Argulus with chemical substance that overdose can pollute the environment, therefore the alternative chemical substance that safe in the environment need to be finded, such as abate. The aims of this study were to determine the effectiveness of abate immersion to demoting the infestation degree and impairing the organ of Argulus in goldfish (Cyprinus carpio). Treatment of this study consisted of five treatment and four replication, i.e $0 \mathrm{ppm}$ (control), $25 \mathrm{ppm}, 50 \mathrm{ppm}, 75 \mathrm{ppm}$ and $100 \mathrm{ppm}$ that immersed for 30 minutes, respectively. The observed parameters were infestation degrees of Argulus, impairing organ of Argulus and water quality before and after the treatment. Degrees of infestation was analyzed by ANOVA 5\% and DMRT 5\%, impairing organ of Argulus was analyzed descriptively by picture and table. The result showed that immersion of abate was not effective to demoting the infestation degrees of Argulus in goldfish. Nevertheless, in the highest treatment (100 ppm) could impairing the organ of Argulus, i.e lose of third and fourth legs, abdomen merged and production of premature egg. Further study was needed to determine the effectiveness of abate immersion at a higher dose and longer incubation time. Furthermore, the physiological effect during the immersion need to be studied.
\end{abstract}

Keywords : Degree of infestation, Organ damage, Abate, Argulus 


\section{PENDAHULUAN}

Perkembangan budidaya ikan hias air tawar, termasuk ikan mas (Cyprinus carpio), semakin meningkat setiap tahunnya sehingga banyak dibudidayakan secara intensif dengan padat tebar tinggi. Tingginya padat tebar menimbulkan permasalahan baru yaitu munculnya serangan parasit Argulus yang dapat menyebabkan penyakit Argulosis ikan mas (Cyprinus carpio) (Juniarsih dkk., 2017). Argulus termasuk dalam golongan ektoparasit yang menempel pada kulit, sirip, dan insang ikan. Ikan yang terinfestasi Argulus akan mengalami kehilangan nafsu makan sehingga akan terlihat kurus, timbul bercak merah pada area penempelan Argulus (Hogans, 1994).

Kematian ikan akibat serangan parasit Argulus dikarenakan ikan mengalami emasiasi sehingga dapat menurunkan sistem kekebalan tubuh ikan. Selain itu munculnya luka pada kulit ikan akan dimanfaatkan sebagai port of entry bagi agen infeksi sekunder seperti jamur, bakteri dan virus (Sumiati dan Aryati, 2010). Hasil penelitian Ulkhaq dkk. (2017) menyebutkan bahwa benih ikan mas (Cyprinus carpio) di Balai Benih Ikan Kabat, Banyuwangi terinfestasi beberapa ektoparasit, salah satunya yaitu Argulus. Lebih lanjut Ulkhaq dkk. (2018) menyatakan bahwa ikan hias air tawar yang dibudidayakan di Kota Banyuwangi positif terinfestasi ektoparasit Argulus. Hal tersebut menunjukkan bahwa Argulus merupakan jenis ektoparasit yang berpotensi menimbulkan kematian pada ikan mas.

Sampai saat ini upaya pengendalian Argulus yang terbukti efektif adalah penggunaan methylen blue dan dimilin. Selain harganya yang mahal, penggunaan dalam jangka panjang dan tidak tepat dosis ternyata berdampak pada pencemaran lingkungan. Sehingga perlu dicari alternatif bahan kimia lain yang efektif untuk pengendalian penyakit Argulosis dan aman terhadap lingkungan perairan. Salah satunya adalah insektisida abate dengan kandungan aktif abate (WHO, 2009).
Insektisida ini umum digunakan untuk membasmi larva nyamuk. Mekanisme kerja dari abate yaitu menghambat kerja enzim asetilkolinesterase maupun pseudokolinesterase dengan mencegah hidrolisa dan inaktifasi asetilkolin pada serabut saraf sehingga terjadi hambatan transmisi sinyal syaraf dan kerusakan pada sistem syaraf simpatis-parasimpatis, syaraf perifer dan syaraf pusat (Gholivand et al., 2014). Abate merupakan insektisida yang paling aman untuk kebanyakan jenis ikan dan vertebrata lain serta memiliki daya toksisitas yang rendah dibandingkan jenis insektisida lain (Mc Leod et al., 1979)

Abate merupakan salah satu larvasida yang tidak menimbulkan residu pada organisme akuatik termasuk ikan, burung dan vertebrata lain (Simpson, 1993). Efektivitas abate sebagai pengendali infestasi ektoparasit pada ikan air tawar telah diteliti oleh Perdana dkk. (2013) yang menyatakan bahwa abate efektif membunuh beberapa ektoparasit ikan air tawar salah satunya yaitu Argulus. Mc Leod et al. (1979) menyatakan bahwa konsentrasi abate yang dapat digunakan untuk mengendalikan populasi krustasea, polichaeta, dan moluska harus berada pada kisaran $40-300$ ppb.

Penelitian mengenai pengaruh perendaman abate terhadap derajat infestasi dan kerusakan organ parasit Argulus yang menginfestasi ikan mas masih belum dilakukan. Tujuan dari penelitian ini adalah untuk mengetahui efektivitas perendaman abate untuk menurunkan derajat infestasi dan merusak organ parasit Argulus yang menginfestasi ikan mas (Cyprinus carpio). Hasil penelitian ini diharapkan dapat menjadi alternatif pengendalian parasit Argulus yang mudah, murah dan aman bagi ikan dan lingkungan perairan.

\section{METODOLOGI \\ Waktu dan Tempat}

Penelitian ini dilaksanakan selama 3 bulan yaitu pada bulan Juli-September 2018 di Laboratorium Basah PSDKU Universitas Airlangga Kampus Banyuwangi. 


\section{Materi Penelitian}

Peralatan yang digunakan dalam penelitian ini yaitu toples plastik berdiameter $20 \mathrm{~cm}$, gelas plastik, mikroskop binocular (Nikon, Inggris), selang plastik, batu aerasi, aerator, alat bedah, nampan plastik, stopwatch, $\mathrm{pH}$ meter, DO meter, termometer dan amonia test kit. Bahan yang digunakan dalam penelitian ini yaitu ikan mas yang berukuran 5-7 cm sejumlah 200 ekor dan parasit Argulus yang diperoleh dari pembudidaya di Banyuwangi, bubuk abate, pakan komersial dengan kadar protein $30 \%$.

\section{Rancangan Penelitian}

Penelitian ini merupakan penelitian eksperimental laboratoris dengan rancangan acak lengkap (RAL) yang terdiri dari 5 perlakuan dengan 4 ulangan. Perlakuan yang diberikan yaitu:

Perlakuan A : larutan abate dengan konsentrasi 0 ppm (kontrol);

Perlakuan B : larutan abate dengan konsentrasi 25 ppm;

Perlakuan $\mathrm{C}$ : larutan abate dengan konsentrasi 50 ppm;

Perlakuan D : larutan abate dengan konsentrasi 75 ppm, dan

Perlakuan E : larutan abate dengan konsentrasi $100 \mathrm{ppm}$.

\section{Prosedur Kerja \\ Persiapan wadah pemeliharaan}

Toples plastik yang digunakan berukuran diameter $20 \mathrm{~cm}$ yang diisi air sebanyak satu liter. Sebelum digunakan, toples plastik dicuci dengan sabun sampai bersih, kemudian dikeringkan dibawah sinar matahari langsung. Setelah kering, toples plastik diisi air sesuai takaran, dilakukan pengacakan penempatan dan disetting aerasi.

\section{Persiapan ikan dan parasit Argulus}

Ikan yang digunakan dalam penelitian ini adalah ikan mas berukuran $5-7 \mathrm{~cm}$ sejumlah tiga ekor setiap toples plastik yang dilakukan aklimatisasi selama 24 jam. Selanjutnya dilakukan infestasi buatan oleh
15 ekor Argulus untuk setiap toples plastik dan ditunggu hingga seluruh Argulus menempel pada ikan mas.

Infestasi buatan adalah metode penempelan Argulus pada inang secara buatan dengan cara memasukkan ikan dalam gelas plastik berisi $400 \mathrm{~mL}$, kemudian Argulus dimasukkan ke dalam gelas plastik dengan jumlah yang disesuaikan dengan perlakuan dan ditunggu sampai seluruh Argulus menempel pada inang (Yusuf dkk., 2009).

\section{Persiapan larutan abate}

Bubuk abate dilarutkan dalam air sesuai dengan konsentrasi perlakuan. Setelah pembuatan larutan uji selesai, dilakukan pengukuran suhu, $\mathrm{pH}$, DO dan amonia menggunakan masing-masing alat ukur.

\section{Perendaman ikan uji sesuai perlakuan}

Ikan yang telah diinfestasi Argulus selanjutnya dimasukkan ke dalam toples sesuai perlakuan selama 30 menit. Selama perendaman dilakukan pengamatan tingkah laku ikan sambil terus diukur suhu dalam larutan. Pada akhir waktu perendaman dilakukan penghitungan jumlah Argulus yang masih menempel dalam tubuh ikan, pengamatan kerusakan organ Argulus dibawah mikroskop dan pengukuran kualitas air (suhu, pH, DO dan amonia).

Parameter yang diamati pada penelitian ini yaitu derajat infestasi Argulus yang menempel pada ikan mas, kerusakan organ Argulus dan nilai kualitas air pada awal dan akhir perendaman sebagai parameter pendukung. Derajat infestasi dihitung berdasarkan rumus sebagai berikut (Zulfikar dkk., 2012) :

Derajat Infestasi $=\frac{\text { Jumlah parasit lepas }}{\text { Jumlah awal parasit }} \times 100 \%$

\section{Analisis Data}

Data derajat infestasi Argulus pada ikan mas dianalisis menggunakan Analysis of Variance (ANOVA) 95\%, jika berbeda nyata dilanjutkan dengan Uji Jarak Berganda Duncan (Duncan Multiple Range Test/ 
DMRT) 95\%. Data kerusakan organ Argulus dianalisis secara deskriptif dan disajikan dalam bentuk gambar dan tabel serta dihubungkan dengan parameter pendukung.

\section{Derajat Infestasi Argulus}

Hasil penghitungan derajat infestasi Argulus pada ikan mas dapat dilihat pada gambar 1.

\section{HASIL DAN PEMBAHASAN}

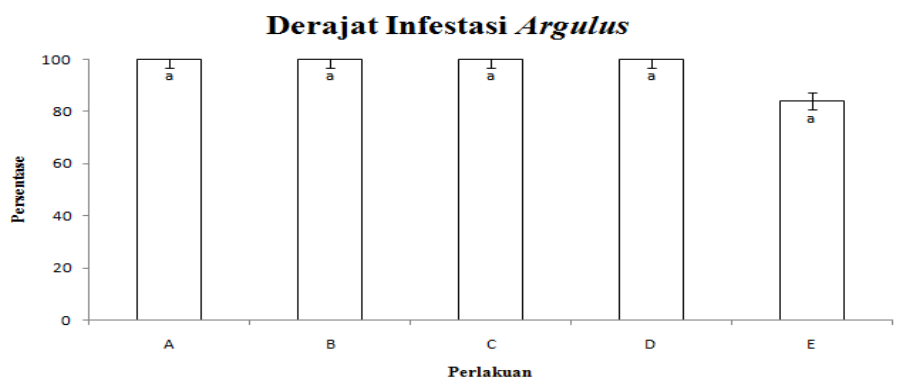

Gambar 1. Derajat infestasi Argulus pada ikan mas

Grafik pada gambar 1 menunjukkan bahwa derajat infestasi Argulus yang masih menempel pada ikan mas setelah direndam dalam larutan abate selama 30 menit. Semua perlakuan perendaman abate menunjukkan tidak terdapat perbedaan yang nyata $(\mathrm{P}>0,05)$ terhadap derajat infestasi Argulus. Hal tersebut menunjukkan bahwa perendaman larutan abate tidak efektif untuk melepaskan Argulus dari ikan mas. Hal ini diduga karena telah terjadi resistensi Argulus terhadap abate. Resistensi merupakan sifat organisme yang menunjukkan kekebalan atau ketahanan terhadap suatu jenis senyawa tertentu (Byarugaba 2010).

Resistensi organisme terhadap insektisida terjadi melalui tiga mekanisme yaitu bekerjanya enzim-enzim tertentu dalam tubuh organisme sehingga terjadi peningkatan detoksifikasi oleh organisme, penurunan kepekaan reseptor insektisida pada tubuh organisme dan penghambatan laju penetrasi insektisida melalui kulit atau integumen (Rodriguez et al., 2002).

Berdasarkan mekanisme terjadinya resistensi tersebut diduga terjadi detoksifikasi oleh Argulus melalui produksi enzim mikrosomal oksidase, glutation transferase, hidrolase dan esterase sehingga Argulus tahan terhadap abate (Roush and Tabashruk, 1990). Selain itu, diduga Argulus juga menghilangkan/memodifikasi struktur kimia dari asetilkolinesterase sehingga terjadi hambatan transmisi sinyal syaraf dan kerusakan pada sistem syaraf simpatis-parasimpatis, syaraf perifer dan syaraf pusat (Gholivand et al., 2014).

Mekanisme resistensi yang ketiga diduga juga dilakukan oleh Argulus yaitu dengan memanfaatkan karapas dalam tubuh Argulus untuk mencegah penetrasi insektisida dalam tubuhnya. Hal ini sesuai dengan pernyataan Olesen (2013) yang menyatakan bahwa fungsi karapas pada krustasea yaitu sebagai alat pernafasan, pengatur hidrodinamika air, alat untuk mengambil makanan, alat pertahanan dan perlindungan diri serta tempat untuk menyimpan telur. Hoffman (1977) menyebutkan bahwa tubuh Argulus terdiri dari kepala, thorax dan abdomen. Bagian kepala sampai thorax tertutupi oleh karapaks yang lebar dan pipih.

Hasil penelitian Hakalahti-Siren (2008) melaporkan bahwa perendaman larutan formalin, $\mathrm{NaCl}$ dan malachite-green tidak efektif untuk membunuh Argulus coregoni. Lebih lanjut Roth (2015) menambahkan bahwa Argulus telah resisten pada pestisida jenis benzyolureas, lindane, avermectins, milbemycins, afoxolaner, dan furalaner. Stecker and Yanong (2012) menjelaskan bahwa pengendalian Argulus yang efektif dapat menggunakan pestisida jenis trichlorfon, diflubenzuron, lufenuron, kalium permanganat, dan emmamectin. 
Tabel 1. Kerusakan organ Argulus pada masing-masing perlakuan

\begin{tabular}{|c|c|c|}
\hline No. & Hasil pengamatan (perbesaran 40x) & Keterangan \\
\hline 1. & Perlakuan A & $\begin{array}{l}\text { Argulus normal, kaki lengkap ( } 4 \\
\text { pasang), maxilla } 1 \text { normal ( } 1 \text { pasang), } \\
\text { karapaks berbentuk lonjong, abdomen } \\
\text { terlihat jelas ( } 1 \text { pasang) dan terdapat } \\
\text { sepasang bintik mata. }\end{array}$ \\
\hline 2. & Perlakuan B & $\begin{array}{l}\text { Argulus normal, kaki lengkap (4 } \\
\text { pasang), maxilla } 1 \text { normal ( } 1 \text { pasang), } \\
\text { karapaks berbentuk lonjong, abdomen } \\
\text { terlihat jelas ( } 1 \text { pasang) dan terdapat } \\
\text { sepasang bintik mata. }\end{array}$ \\
\hline 3. & Perlakuan $\mathrm{C}$ & $\begin{array}{l}\text { Argulus normal, kaki lengkap (4 } \\
\text { pasang), maxilla } 1 \text { normal ( } 1 \text { pasang), } \\
\text { karapaks berbentuk lonjong, abdomen } \\
\text { terlihat jelas ( } 1 \text { pasang) dan terdapat } \\
\text { sepasang bintik mata. }\end{array}$ \\
\hline 4. & Perlakuan D & $\begin{array}{l}\text { Argulus normal, kaki lengkap (4 } \\
\text { pasang), maxilla } 1 \text { normal ( } 1 \text { pasang), } \\
\text { karapaks berbentuk lonjong, abdomen } \\
\text { terlihat jelas ( } 1 \text { pasang) dan terdapat } \\
\text { sepasang bintik mata. }\end{array}$ \\
\hline 5. & Perlakuan E & $\begin{array}{l}\text { Argulus terlihat tidak normal, } \\
\text { pasangan kaki ke-3 dan } 4 \text { rontok (A), } \\
\text { abdomen terlihat menyatu (B), } \\
\text { mengeluarkan telur prematur }(\mathrm{C})\end{array}$ \\
\hline
\end{tabular}


Hasil pengamatan kerusakan organ Argulus setelah dilakukan perendaman pada larutan abate berbeda dosis terlihat hanya pada perlakuan $\mathrm{E}$ yang mengalami kerusakan. Pada perlakuan A sampai D, Argulus terlihat normal dan tidak terdapat kerusakan organ. Hal ini diduga terjadi karena Argulus telah resisten terhadap abate pada konsentrasi tersebut sehingga tidak berefek pada Argulus. Resistensi dapat terjadi karena Argulus mampu merubah struktur enzim asetilkolinesterase sehingga enzim tersebut menjadi tidak aktif. Enzim asetilkolinesterase dapat mencegah transmisi saraf kolinergik pada parasit sehingga mengakibatkan paralisis (kelumpuhan) yang akhirnya dapat mematikan parasit tersebut (Athanassopoulou et al., 2009).

Kerusakan organ yang terjadi pada perlakuan E yaitu rontoknya kaki ke-3 dan 4 , abdomen yang menyatu serta produksi telur yang prematur. Alas et al., (2008) menyebutkan bahwa morfologi normal Argulus yaitu memiliki bentuk tubuh yang oval, lebar, pipih dorsoventral, terdapat sepasang mata faset. Tubuh terdiri dari tiga bagian yaitu cephalothorax, thorax dan abdomen (urosome). Bagian cephalothorax ditutupi oleh karapas yang lebar. Maksilla 1 dan 2 digunakan untuk menempel pada inang. Dilengkapi 4 pasang kaki renang yang terletak pada bagian thorax. Bagian abdomen memiliki sepasang lubang ekskresi.

Rontoknya kaki ke-3 dan 4 serta abdomen yang menyatu diduga karena Argulus mengalami gangguan saraf karena kinerja enzim asetilkolinesterase yang akhirnya menyebabkan otot menjadi tidak bekerja dan mengalami kelumpuhan.

Hal ini akan mempengaruhi kemampuan Argulus untuk mencari inang, bereproduksi dan proses metabolisme dalam tubuhnya. Hoffman (1977) menyatakan bahwa kaki Argulus berjumlah empat pasang yang ber-fungsi sebagai alat untuk berenang mencari inang (swimming leg) sedangkan abdomen di bagian posterior berfungsi sebagai alat pengeluaran telur (betina) dan sperma (jantan) serta sebagai alat ekskresi hasil metabolisme.

Produksi telur yang prematur pada Argulus diduga merupakan sebagai strategi untuk mempertahankan diri terhadap kondisi lingkungan yang tidak menguntungkan. Hoeg et al., (2005) menyatakan bahwa parasit krustasea akan memproduksi telur saat telur matang atau dalam kondisi yang tidak menguntungkan, diantaranya suhu yang ekstrim (Hakalahti et al., 2004) atau terpapar bahan kimia (Parvez et al., 2013). Hasil penelitian Sahoo et al. (2013) menyatakan bahwa perkembangan telur Argulus yang optimal terjadi pada suhu 28 ${ }^{\circ} \mathrm{C}$.

Parvez et al. (2013) menyebutkan bahwa telur Argulus yang terpapar insektisida jenis Chlorvar memiliki tingkat penetasan telur (hatching rate) paling besar (38\%) dibandingkan jenis insektisida lain (Byotrol, Netrex, ekstrak jeruk nipis dan bawang).

\section{Pengukuran Kualitas Air}

Hasil pengukuran kualitas air selama perlakuan dapat dilihat pada tabel 2 .

Tabel 2. Hasil pengukuran kualitas air selama perlakuan

\begin{tabular}{ccccc}
\hline Perlakuan & Suhu $\left({ }^{\circ} \mathrm{C}\right)$ & DO $(\mathrm{mg} / \mathrm{l})$ & Amonia $(\mathrm{ppm})$ & $\mathrm{pH}$ \\
\hline $\mathrm{A}$ & 26 & 6 & 0 & 7,2 \\
$\mathrm{~B}$ & 25 & 6 & 0 & 7,3 \\
$\mathrm{C}$ & 25 & 5 & 0 & 7,2 \\
$\mathrm{D}$ & 26 & 6 & 0 & 7,4 \\
E & 25 & 6 & 0 & 7,1 \\
Literatur & $25-27$ & $5-7$ & 0,1 & $7-8,5$ \\
(SNI, 1999) & & & &
\end{tabular}


Berdasarkan hasil pengukuran parameter kualitas air di atas menunjukkan bahwa nilai kualitas air selama penelitian masih dalam kisaran yang ditetapkan dalam SNI (1999) sehingga tidak mempengaruhi kehidupan ikan. Suhu pada air mempengaruhi kecepatan reaksi kimia, baik dalam media luar maupun air (cairan) dalam tubuh ikan.

Suhu rendah akan mengurangi imunitas (kekebalan tubuh) ikan, sedangkan suhu tinggi akan mempercepat ikan terkena infeksi bakteri (Undap dan Tumbol, 2016). Oksigen terlarut dalam air dibutuhkan untuk proses pernafasan, metabolisme, oksidasi dan reduksi bahan-bahan organik dan anorganik dalam proses aerob. Kandungan oksigen yang rendah akan menyebabkan hypoxia pada organisme perairan yang berujung pada kematian (Salmin, 2005).

Kandungan amonia yang tinggi pada perairan menyebabkan kerusakan pada fungsi dan struktur organ, yaitu penyempitan permukaan insang, penurunan jumlah sel darah, penurunan kadar oksigen dalam darah, penurunan sistem imun dan kerusakan sel parenkim hati (Sutomo, 1989). Derajat keasaman $(\mathrm{pH})$ merupakan salah satu parameter kualitas air yang menentukan kehidupan organisme perairan. $\mathrm{pH}$ yang sangat rendah, menyebabkan kelarutan logam-logam dalam air makin besar, yang bersifat toksik bagi organisme air.

Sebaliknya $\mathrm{pH}$ yang tinggi dapat meningkatkan konsentrasi amoniak dalam air yang juga bersifat toksik bagi organisme air (Tatangindatu dkk., 2013). Dampak perubahan $\mathrm{pH}$ secara ekstrem dan melebihi standar acuan, dapat menyebabkan terganggunya metabolisme, pertumbuhan menurun, dan ikan mudah terserang penyakit dan stress (Pramleonita dkk., 2018).

\section{KESIMPULAN DAN SARAN Kesimpulan}

Kesimpulan dari hasil penelitian ini adalah perendaman abate tidak efektif untuk menurunkan derajat infestasi menginfestasi ikan mas (C. carpio), akan tetapi dapat menimbulkan kerusakan organ Argulus pada perlakuan 100 ppm. Kerusakan organ Argulus yang ditimbulkan yaitu rontoknya kaki ke-3 dan 4, abdomen yang menyatu serta produksi telur prematur.

\section{Saran}

Perlu dilakukan penelitian lanjutan dengan meningkatkan dosis abate (lebih dari $100 \mathrm{ppm}$ ) serta waktu inkubasi yang lebih lama (lebih dari 30 menit). Selain itu perlu diamati perubahan fisiologis ikan selama dilakukan perendaman dalam abate.

\section{DAFTAR PUSTAKA}

Alas, A., Oktener, A., and Solak, K. 2010. A study on the morphology of Argulus foliaceus Lin., 1758 (Crustacea: Branchiura) procured from Cavuscu Lake (Central Anatolia-Turkey) with Scanning Electron Microscopy. Turk. J. Biol., 34, p.147-151.

Athanassopoulou F., Pappas, I.S., and Bitchava, K. 2009. An overview of the treatment for parasitic disease in Mediterranean aquaculture. Options Méditerr Ser A, 86, p.65-83.

Bandilla, M. 2007. Transmission and host and mate location in the fish louse Argulus coregoni and its link with bacterial disease in fish. Dissertation. Faculty of Mathematics and Science. University of Jyvaskyla. 43p.

Byarugaba, D.K. 2010. Mechanisms of antimicrobial resistence. In: Antimicrobial Resistance in Developing Countries. Springer, New York, NY, 2010. p. 15-26.

Gholivand, K., Valmoozi, A.A.E., and Bonsali, M. 2014. Synthesis and crystal structure of new abate analogue as cholinesterase inhibitor: molecular docking, QSAR Study, and hydrogen bonding analysis of solid state. Journal of Agricultural and Food Chemistry, 62(25), p.57615771.

Hakalahti, T., Hakkinen, H., Valtonon., E.T. 2004. Ectoparasitic Argulus coregoni (crustacea: branchiura) 
hedge their bets- studies on egg hatching dynamics. Oikos, 107(2), p.295-302.

Halakahti-Siren, T., Mikheev, V.N., and Valtonen, E.T. 2008. Control of freshwater fish louse Argulus coregoni: a step toward an integrated management strategy. Dis Aquat Org, 82, p.67-77.

Hastono, S.D. 2016. Argulusiasis pada ikan koi. Prosiding KIVNAS ke-14, ICEBSD City Tangerang 22-25 September 2016. pp.17-18.

Hoeg, J., Glenner, H., and Shields, J.D. 2005. Cirripedia thoracica and rhizocephala (barnacles), in: Rohde, K. (Ed.) Marine parasitology. CSIRO Publishing.

Hoffman, G.L. 1977. Argulus, a branchiuran parasite of freshwater fishes. US Fish and Wildlife Service Publication.

Hogans, B. 1994. Branchiuran fish louse disease. Atlantic Reference Center. Huntsman Marine Science Center. Canada.

Juniarsih, A., Mahasri, G., and Kismiyati. 2017. Infestasi Argulus pada ikan mas (Cyprinus carpio) di Dasar Kolam Tanah dan Beton, Kecamatan Muntilan dan Mungkid, Kabupaten Magelang. Journal of Aquaculture and Fish Health, 6(2), p.74-80.

Kabata, Z. 1985. Parasites and diseases of fish cultured in the tropics. Taylor and Francis. London and Philadelphia. 318 p.

Kusriningrum. 2008. Perancangan percobaan. Fakultas Kedokteran Hewan. Universitas Airlangga. Airlangga University Press. Surabaya.

Noaman, V., Chelongar, Y., and Shahmoradi, A.H. 2010. The first record of Argulus foliacesus (crustacea: branchiura) infestation on lionhead goldfish (Carassius auratus) in Iran. Iranian J. Parasitol, 5(2), p.71-76.
Ode, I. 2012. Argulus: Ektoparasit pada Ikan. Bimafika 4. p.413-416.

Olesen, J.,2013. The crustacean carapace: morphology, function, development, and phylogenetic history. In: Les W., Martin T. 2013. Functional Morphology and Diversity. Oxford University Press.

Parvez, M.M., Bhuyain, M.A.B., Shahabuddin, A.M., Farque,A.R., and Shine, S. 2013. Environmentally sustainable control measure of Argulus on freshwater ponds in Bangladesh. Int. J. Sustain. Agril. Tech, 9(1), p.64-70.

Paternak, A.F., Mikheev, V.N., and Valtonen, E.T. 2000. Life history characteristic of Argulus foliaceus L. (crustacea: branchiura) population in Central Finland. Ann. Zool. Fennici, 37, p.25-35.

Perdana, O.K.N., Hilyana, S., and Setyowati, D.N. 2013. Efektivitas abate terhadap prevalensi dan intensitas rata-rata ektoparasit pada ikan maskoki (Carassius auratus). Jurnal Perikanan Unram, 3, p.1-6.

Pramleonita, M., Yuliani, N., Arizal, R., and Wardoyo, S.E. 2018. Parameter fisika dan kimia air kolam ikan nila hitam. Jurnal Sains Natural Univesitas Nusa Bangsa, 8(1), p.2434.

Radkhah, A.R. 2017. Introduction to some spesies of argulus (crustacea: branchiura), parasitic infection in the freshwater fishes. J.Appl.Sci.Environ.Manage, 21(7), p.1268-1271.

Rodriguez, M.M, Bisset, J., and Ruiz, M.S.A. 2002. Cross-resistance to pyrethroid and organophosphorus insecticides induced by selection with abate in Aedes aegypti (Diptera : Cullicidae) from Cuba. $J \mathrm{Med}$ Entomol., 39, p.882-888.

Roth, M., 2015. Management of sea lice on farmed salmon with veterinary medicines and biological control 
strategies. International Animal Health Journal, 2(3), p.32-37.

Roush, R.T., and Tabashnik, B.E., 1990. Pesticide resistance in arthopods. Chapman \& Hall. Inc, Great Britain. p. 311.

Sahoo, P.K., Mohanty, J., Hemaprasanth, Kar, B., Mohanty, B.K., Garnayak, S.K., and Jena, J.K., 2013. Egg laying strategies and effect of temperature on egg development of Argulus siamensis. J.Parasit Dis., 37(2), p.158-162.

Salmin., 2005. Oksigen terlarut (DO) dan kebutuhan oksigen biologi (BOD) sebagai salah satu indikator untuk menentukan kualitas perairan. Oseana, 30(3), p.21-26.

Silalahi, G.A., 2006. Metodologi penelitian. PT. Raja Grafindo Persada. Jakarta. 165 hal.

Simpson, L.C., 1993. The impact of agricultural practices on the aquatic invertebrate food supply of fish in ricefields. Paper presented at the Third Regional Rice-Fish Farming Research and Development Workshop, June 6-11, SW, Sukamandi, Indonesia.

SNI (Standar Nasional Indonesia) : 016311-1999., 1999. Produksi benih ikan mas (Cyprinus carpio) strain Majalaya kelas benih sebar. Badan Standardisasi Nasional Indonesia. p.11.

Steckler, N., and Yanong, R.P.E., 2012. Argulus (fish louse) infection in fish. IFAS Extension 184. University of Florida. p.4.

Sumiati, T., and Aryati, Y., 2010. Penyakit parasitik pada ikan hias air tawar. Prosiding Forum Inovasi Teknologi Akuakultur, p.963-967.

Sutomo., 1989. Pengaruh Amonia terhadap ikan dalam budidaya sistem tertutup. Oseana, 14(1), p.19-26.

Tatangidatu, F., Kalesaran, O., and Rompas, R., 2013. Studi parameter fisika kimia air pada areal budidaya ikan di Danau Tondano, Desa
Paleloan, Kabupaten Minahasa. Budidaya Perairan, 1(2), p.8-19.

Ulkhaq, M.F., Budi, D.S., and Kismiyati., 2018. inventarisasi ektoparasit protozoa dan arthropoda yang menginfestasi ikan air tawar di Kota Banyuwangi, Jawa Timur. Journal of Aquaculture Science, 3(2), p.108115.

Ulkhaq, M.F., Budi, D.S., Mahasri, G., and Kismiyati., 2017. Identifikasi ektoparasit pada benih ikan mas (Cyprinus carpio) di Balai Benih Ikan Kabat, Kabupaten Banyuwangi. Jurnal Sains Veteriner, 35(2), p.197207.

Undap, S.L., and Tumbol, R.A., 2016. Pengelolaan kualitas air Danau Tutud untuk budidaya ikan di Sulawesi Utara. Jurnal Ilmiah Platax 4(2): 130-138.

World Health Organization (WHO)., 2009. Abate in drinking water: use for vector control in drinking-water sources and containers. WHO Press, Geneva, Switzerland. 14 p.

Yusuf, R.W.N. 2009. Isolasi dan identifikasi bakteri gram negatif pada luka ikan maskoki (Carassius auratus) akibat infestasi ektoparasit Argulus sp. Skripsi. Fakultas Perikanan dan Kelautan. Universitas Airlangga. Surabaya.

Zulfikar, Hambal, and Razali. 2012. Derajat infestasi parasit nematoda gastrointestinal pada sapi di Aceh Bagian Tengah. Lentera, 12(3), p.17. 